\title{
The History, Challenges, and New Developments in the Management and Use of Bauxite Residue
}

\author{
Ken Evans ${ }^{1}$
}

Published online: 19 May 2016

(C) The Minerals, Metals \& Materials Society (TMS) 2016

\begin{abstract}
The paper serves to briefly review the disposal and storage of bauxite residue from the late nineteenth century and discusses how the environmental aspects of storage and disposal have changed. The paper describes some of the remediation/rehabilitation trends and describes the success of a soil-free approach in Jamaica. The paper further discusses the development of uses for bauxite residue over the same period. In spite of over a century of effort looking for uses, over 1200 patents and hundreds of technically successful trials, less than 4 million tonnes of the 150 million tonnes of bauxite residue produced annually is used in a productive way. A large proportion of material that is used is in China and driven by government pressure. This paper discusses the barriers and why the technical successes do not always translate into largescale uses. The most successful large-scale uses are reviewed and include cement production, raw material for iron and steel manufacture, manufacture of building materials, landfill capping, road construction, and soil amelioration. Some of the more recent promising developments are also presented.
\end{abstract}

Keywords Bauxite residue $\cdot$ Red mud · Use · Remediation $\cdot$ Storage $\cdot$ Management

The contributing editor for this article was Yiannis Pontikes.

\author{
Ken Evans \\ ken.evans111@btinternet.com \\ 1 ETCL, 4 Hillfield Road, Chalfont St. Peter SL9 0DX, UK
}

\section{Introduction}

The paper serves as a brief overview of the history and trends in the management and use of bauxite residue, outlining: the dimensions of the problem; the characteristics of bauxite residue; how methods of storage and disposal have developed over time and the implications for bauxite residue use; an example of a soil less free rehabilitation method; the technically successful uses; the challenges to implementation-real and perceived; a review of large-scale/industrial scale successes; and some recent innovations.

Annual production of smelter grade and chemical grade alumina in 2015 was over 115 million tonnes [1], which, with the exception of some plants in Russia, Iran, and China, is all produced using the Bayer process. The global average of bauxite residue generated per tonne of alumina is between 1 and 1.5 tonnes, though the amounts from different plants are much broader; it is estimated that over 150 million tonnes of bauxite residue are produced annually. The quantity of bauxite residue generated at a particular refinery is governed by the processing conditions and bauxite quality; the key bauxite characteristics are the alumina content, the nature of the aluminum hydrous-oxide component present (whether as gibbsite, boehmite or diaspore), and reactive and crystalline silica contents. The processing conditions are driven by energy and transport costs: in general when long bauxite transport distances are involved, a higher quality of bauxite is used together with more aggressive extraction conditions. For example, many alumina refineries in Western Europe and North America use bauxite transported for distant countries such as Guinea, Brazil, and Jamaica while in Australia, the bauxite deposits are often located relatively close to the refinery. As a result, in Eurpoean plants, the average quantity of 
bauxite residue produced per tonne of alumina is $0.67 \mathrm{t}$ while the global average is considerably higher at $1.35 \mathrm{t}$ [2]. Currently there are about 80 active Bayer plants of which approximately 30 are in China. In addition, there are at least another 50 closed legacy sites so the combined stockpile of bauxite residue at active and legacy sites is estimated at three thousand million tonnes [3].

\section{Bauxite Residue Characteristics}

The key first steps in discussing uses is a consideration of the chemical compounds present in the bauxite residue, the levels present and the physical characteristics of the material. The variation in composition is extremely wide as shown in Table 1 [3]; these data represent values for commonly used bauxites and the range can be even broader for some bauxites [3].

A wide range of other components may also be present at low levels; these will invariably be as metallic oxides, e.g., arsenic, beryllium, cadmium, chromium, copper, gallium, lead, manganese, mercury, nickel, potassium, scandium, thorium, uranium, vanadium, zinc, zirconium, and rare earth elements (REEs). Non-metallic elements that may occur in the bauxite residue are phosphorus, carbon, and sulfur.

The minerals present are complex and comprise some which are present in the bauxite and others that are produced during the autoclaving and the desilication processes. The range of minerals typically found for bauxite residues is shown in Table 2 [3].

In addition, there are various other minerals sometimes found at low levels including brookite (an orthorhombic variant of $\left.\mathrm{TiO}_{2}\right)$, ilmenite $(\mathrm{FeTiO})$, carnegieite $\left(\mathrm{Si}_{4} \mathrm{Al}_{4}\right.$ $\left.\mathrm{Na}_{4} \mathrm{O}_{16}\right)$, dolomite $\left(\mathrm{CaMg}\left(\mathrm{CO}_{3}\right)_{2}\right)$, hydrogarnet $\left(\mathrm{Ca}_{3} \mathrm{Al}_{2}\right.$ $\left.\left(\mathrm{O}_{4} \mathrm{H}_{4}\right)_{3}\right)$, various hydroxycancrinite/cancrinite $\left(\mathrm{Na}_{6} \mathrm{Ca}_{2}\right.$ $\left.\left(\mathrm{Al}_{6} \mathrm{Si}_{6} \mathrm{O}_{24}\right)\left(\mathrm{CO}_{3}\right)_{2} \cdot 2 \mathrm{H}_{2} \mathrm{O}\right), \quad(\mathrm{Na}, \mathrm{Ca})_{8}(\mathrm{Al}, \mathrm{Si})_{12} \mathrm{O}_{24}\left(\mathrm{CO}_{3}\right)-$ $\left.4 \mathrm{H}_{2} \mathrm{O}\right)$, cancrinite- $\mathrm{NO}_{3} \quad\left(\mathrm{Na}_{7.92} \mathrm{Si}_{6} \mathrm{Al}_{6} \mathrm{O}_{31.56} \mathrm{~N}_{1.74}\right)$, cancrisilite- $\mathrm{CO}_{3}\left(\mathrm{Na}_{7.86}\left(\mathrm{AlSiO}_{4}\right)_{6}\left(\mathrm{CO}_{3}\right)\left(\mathrm{H}_{2} \mathrm{O}\right)_{3.3}\right)$, katoite-Si $\left(\mathrm{Ca}_{3} \mathrm{Al}_{2}\left(\mathrm{SiO}_{4}\right)(\mathrm{OH})_{8}\right)$, lawsonite $\left(\mathrm{CaAl}_{2} \mathrm{Si}_{2} \mathrm{O}_{7}(\mathrm{OH})_{2} \cdot \mathrm{H}_{2} \mathrm{O}\right)$, nepheline $\left(\mathrm{Na}_{2} \mathrm{KAl}_{4} \mathrm{Si}_{4} \mathrm{O}_{16}\right)$, nosean $\left(\mathrm{Na}_{8} \mathrm{Al}_{6} \mathrm{Si}_{6} \mathrm{O}_{24}\left(\mathrm{SO}_{4}\right)\right)$,

Table 1 Chemical composition, expressed as oxides, commonly found in bauxite residue

\begin{tabular}{ll}
\hline Component & Typical range (wt\%) \\
\hline $\mathrm{Fe}_{2} \mathrm{O}_{3}$ & $5-60$ \\
$\mathrm{Al}_{2} \mathrm{O}_{3}$ & $5-30$ \\
$\mathrm{TiO}_{2}$ & $0.3-15$ \\
$\mathrm{CaO}$ & $2-14$ \\
$\mathrm{SiO}_{2}$ & $3-50$ \\
$\mathrm{Na}_{2} \mathrm{O}$ & $1-10$ \\
$\mathrm{LOM}$ & $5-20$ \\
\hline
\end{tabular}

Table 2 Typical range of components found in bauxite residues

\begin{tabular}{ll}
\hline Component & Typical range $(\mathrm{wt} \%)$ \\
\hline Sodalite $\left(3 \mathrm{Na}_{2} \mathrm{O} \cdot 3 \mathrm{Al}_{2} \mathrm{O}_{3} \cdot 6 \mathrm{SiO}_{2} \cdot \mathrm{Na}_{2} \mathrm{SO}_{4}\right)$ & $4-40$ \\
Al-goethite $\left((\mathrm{Fe}, \mathrm{Al})_{2} \mathrm{O}_{3} \cdot \mathrm{nH}_{2} \mathrm{O}\right)$ & $1-55$ \\
Haematite $\left(\mathrm{Fe}_{2} \mathrm{O}_{3}\right)$ & $10-30$ \\
Magnetite $\left(\mathrm{Fe}_{3} \mathrm{O}_{4}\right)$ & $0-8$ \\
Silica $\left(\mathrm{SiO}_{2}\right)$ crystalline and amorphous & $3-20$ \\
Calcium aluminate $\left(3 \mathrm{CaO} \cdot \mathrm{Al}_{2} \mathrm{O}_{3} \cdot 6 \mathrm{H}_{2} \mathrm{O}\right)$ & $2-20$ \\
Boehmite $(\mathrm{AlOOH})$ & $0-20$ \\
Titanium $\mathrm{Dioxide}\left(\mathrm{TiO}_{2}\right)$ anatase and rutile & $2-15$ \\
Muscovite $\left(\mathrm{K}_{2} \mathrm{O} \cdot 3 \mathrm{Al}_{2} \mathrm{O}_{3} \cdot 6 \mathrm{SiO}_{2} \cdot 2 \mathrm{H}_{2} \mathrm{O}\right)$ & $0-15$ \\
Calcite $(\mathrm{CaCO})$ & $2-20$ \\
Kaolinite $\left(\mathrm{Al}_{2} \mathrm{O}_{3} \cdot 2 \mathrm{SiO}_{2} \cdot 2 \mathrm{H}_{2} \mathrm{O}\right)$ & $0-5$ \\
Gibbsite $\left(\mathrm{Al}(\mathrm{OH})_{3}\right)$ & $0-5$ \\
Perovskite $(\mathrm{CaTiO}$ & $0-12$ \\
Cancrinite $\left(\mathrm{Na}_{6}\left[\mathrm{Al}_{6} \mathrm{Si}_{6} \mathrm{O}_{24}\right] \cdot 2 \mathrm{CaCO}_{3}\right)$ & $0-50$ \\
Diaspore $(\mathrm{AlOOH}$ & $0-5$ \\
\hline
\end{tabular}

portlandite $\left(\mathrm{Ca}(\mathrm{OH})_{2}\right)$, schaeferite $\left(\left(\mathrm{Na}_{0.7} \mathrm{Ca}_{.2 .3}\right)\left(\mathrm{Mg}_{1.85}\right.\right.$ $\left.\left.\mathrm{Mn}_{0.15}\right)\left(\mathrm{VO}_{4}\right)_{2.88}\left(\mathrm{PO}_{4}\right)_{0.12}\right)$ ), sodium titanate $\left(\mathrm{Na}_{2} \mathrm{TiO}_{3}\right)$, and zircon $\left(\mathrm{ZrSiO}_{4}\right)$ [4].

Sodium is the only element not found in the bauxite itself. Some of the elements are soluble in the Bayer process and either build up in the Bayer liquor or precipitate along with the aluminum hydroxide. Depending on their solubility and the temperature used in the extraction process, some elements will increase in concentration in the bauxite residue relative to the bauxite while others will be lower in the bauxite residue. Other than caustic soda, lime is normally the only other inorganic compound introduced during the Bayer process.

A wide variety of organic compounds can also be present, these are derived from vegetable and organic matter in the bauxite/overburden or the use of crystal growth modifiers or flocculants and includes carbohydrates, alcohols, phenols, and the sodium salts of polybasic and hydroxyacids such as humic, fulvic, succinic, acetic, or oxalic acids.

The sodium in bauxite residue may be present in a sparingly soluble form, called the desilication product (DSP) or a very soluble form. The small quantities of some of the soluble sodium compounds resulting from the sodium hydroxide used in the extraction process will remain depending on the dewatering and washing systems used. All Bayer alumina refineries try to maximize the recovery of the valuable caustic soda from the residues in order to reuse it during the extraction process. The residual soluble sodium species, predominantly a mixture of sodium aluminate and sodium carbonate, give rise to an elevated $\mathrm{pH}$ for bauxite residue slurries. Over time, the residual sodium species are partially neutralized by carbon dioxide from the air to form sodium carbonate and other metal 
carbonate species; these species will result in a lower $\mathrm{pH}$ for the bauxite residue which renders them less hazardous. The desilication product $\left(3 \mathrm{Na}_{2} \mathrm{O} \cdot \mathrm{Al}_{2} \mathrm{O}_{2} \cdot 2 \mathrm{SiO}_{2} \cdot 0-2 \mathrm{H}_{2}\right.$ $\mathrm{O} \cdot 2 \mathrm{NaX}$ where $\mathrm{X}$ could be $\mathrm{CO}_{3}{ }^{2-}, \mathrm{Cl}^{-}, \mathrm{OH}^{-}, \mathrm{SO}_{4}{ }^{2-}$, or $\left.\mathrm{Al}(\mathrm{OH})_{4}^{-}\right)$arises from the reaction between sodium aluminate and soluble sodium silicates.

The other factors that are important when considering uses are the physical characteristics such as particle size distribution and some variable parameters such as moisture content. The median particle size is normally in the range of $5-10 \mu \mathrm{m}$, however, the breadth of particles is both very broad ranging from coarse sandy grains about $1 \mathrm{~mm}$ in size down to sub-micron particles for bauxite residues produced from different alumina plants and different bauxites. Some alumina refineries separate the different size fractions during processing while others do not; the coarse sandy fraction has been given various names, for example "Red Sand ${ }^{\mathrm{TM}}$ " or "Red Oxide Sand."

It should be noted that bauxite residue or red mud has been called a variety of names by different companies, sometimes after additional treatment and some of the names are registered trademarks. These names include Bauxaline $^{\circledR}$, Alkaloam ${ }^{\mathrm{TM}}$, Red Oxide Sand, Red Sand ${ }^{\mathrm{TM}}$, Ferraloks, Bauxsol $^{\circledR}$, ReadyGrit ${ }^{\mathrm{TM}}$, BPR-Bayer Process Residue, ARR-Alumina Refinery Residue, Bauxite tailings, Ferroalumina, Ferraloks, ART-Alumina refinery tailings, Redmedite, TerraB ${ }^{\mathrm{TM}}$, ViroMine ${ }^{\mathrm{TM}}$, ViroSoils ${ }^{\mathrm{TM}}$, ViroSewage $^{\mathrm{TM}}$, Cajunite $^{\mathrm{TM}}$, and RMG. Bauxite residue is arguably a more inclusive name as some alumina refineries separate the coarse high silica sandy fraction from the fine muds; some of the muds are brown rather than red; and some diasporic-derived residues are almost black in color. However, the name "red mud" still tends to be more commonly used in North America and Europe.

\section{History and Trends in Disposal and Storage Methods}

Management and methods of storage of bauxite residue have evolved progressively over the decades $[3,5]$. In the early Bayer alumina plants, the residue generated was often merely piled up on site or an area adjoining the alumina plant. Occasionally depleted mine or quarry sites were filled using the bauxite residue. In other situations, residue was disposed of in nearby estuaries or sea lagoons and then later as the closest convenient areas were filled, valleys were dammed to contain the ever growing volumes of residue. These methods of storage were especially true of the early European sites. Some typical examples include Bergheim (Germany), on site storage then in former lignite mines adjacent to the plant. In Burntisland (UK), disposal initially was into an estuary, when this was full, behind a sea wall, see Fig. 1, and later still an old shale mine, see Fig. 2. In Gardanne (France), the residue was stored in a nearby dammed valley then disposal by pipeline to the sea. In La Barasse (France) initially storage was on site, then a nearby dammed valley then disposal to sea via a pipeline. In Larne (UK), disposal was carried out by discharging into sea water lagoons, while in Newport (UK) disposal was initially into an estuary from barges then into lagoons. In Salindres (France), initially on site storage then in a dammed valley. Ludwigshafen (Germany) and Schwandorf (Germany) both used on site storage.

Prior to 1980, most of the inventory of bauxite residue was stored in lagoon-type impoundments and the practice is still carried out at a few facilities. In this method, the bauxite residue slurry from the mud washing circuit is pumped, with a solids content of $18-30 \%$, into storage areas created by dams and other earthworks for secure containment. In many instances, valleys were dammed, for example, Ewarton (Jamaica), see Figs. 3 and 4, Gardanne, Salindres, Saint Cyr (France), Ouro Preto (Brazil). In addition to Bergheim and Burntisland, other examples of old mine storage sites were former bauxite mines at Kirkvine (Jamaica) and the former refineries at Bauxite,



Fig. 1 Bauxite disposal into an estuary to recover land, Burntisland, Scotland 


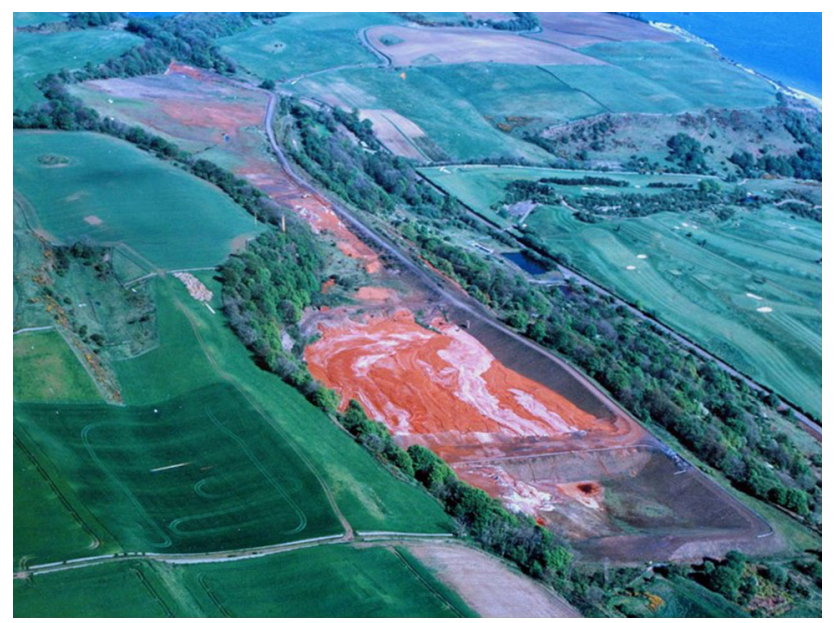

Fig. 2 Bauxite residue disposal into a former oil shale mine, Whinnyhall, Scotland

Arkansas (USA). In the case of sites constructed in the past three or four decades, the storage areas have normally been sealed to minimize leakage to the underlying ground and ground water, however, this tended not to be the practice in earlier years. Sealing approaches cover a range of materials including compacted or impermeable clays and/or the use of plastic and other membrane materials.

The supernatant liquor above the residue was normally returned to the plant for reuse thereby recovering most of the caustic soda value and avoiding contaminating the environment. Various drainage and seepage collection systems have been incorporated into the design and construction of the facilities. The construction of the storage area was often dictated by the type of bauxite residue and differed for clay-like muds compared to more sandy residues. At Gramercy (USA), sand-bed filtration was used and "French Drains" were used with drainage pipes and covering layers of sand of different size and gravel to give



Fig. 3 Bauxite residue disposal into a dammed valley to create a lagoon, early stages, Mount Rosser, Jamaica

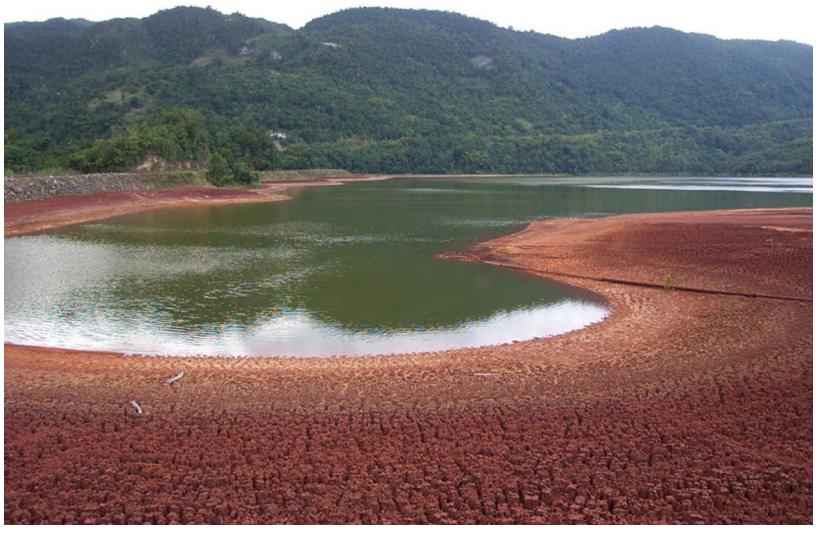

Fig. 4 Bauxite residue disposal into dammed valley, later stages, Mount Rosser, Jamaica

permeability through the base of the lake. This was termed the DREW (Decantation, Drainage and Evaporation of Water) system.

There are many examples of lagoon storage method but they include Stade (Germany), Burnside (USA), and Vaudreuil (Canada). In some cases, low dykes or levees were built to the final expected height at the start and a new area constructed when more volume was required while in others the dam walls were successively increased when the space was filled. The area of suitable land readily available dictated the approach.

If the residue material is not neutralized before discharge to the storage lagoon, it remains a highly alkaline, poorly compacted mud area covered by a highly alkaline lake, see for example, the lake in Fig. 4 which had a $\mathrm{pH}>12$ and a soda level in excess of $2000 \mathrm{mg} / \mathrm{L}$ many years after bauxite residue slurry pumping had stopped. This creates safety and environmental hazards including the potential for contact of humans and wildlife with alkaline liquor and mud, and contamination of surface and ground waters by leaching of caustic liquor and other contaminants. Regrettably, in some cases, these early ponds have proved of limited effectiveness and caustic liquor, plus other contaminants, have subsequently seeped into the surrounding environment. Ongoing remediation of these situations can prove to be a costly exercise. Addressing the risk and to eliminate the potential for catastrophic failure of the dam/impoundment and consequent environmental hazard to the surrounding area/communities introduces high monitoring, maintenance, and remediation costs. Under some circumstances, this has created the prospect of an indefinite legacy.

Another disposal technique adopted by some plants was sea or river disposal particularly in the 1940s to 1960s. In at least six plants, two located in France (Gardanne and La Barasse), one in Greece (Distomon), and three in Japan 
(Shimizu, Ehime and Yokohama), bauxite residue was discharged into the sea either via pipelines or from ocean going vessels. Other alumina plants disposed the residue into rivers or estuaries, for example, into the Mississippi River (Gramercy), and Severn Estuary (Newport). In other cases in Ireland (Larne), Wales (Newport) and Scotland (Burntisland), land was reclaimed from the sea by disposing the residue in tidal lagoons or behind sea walls. River discharge is no longer undertaken with any alumina refining facilities and all sea discharge ceased at the end of 2015.

As land for lagoon storage became scarce for many plants, "Dry stacking" methods were used. A dry stacking regime was adopted nearly 75 years ago in the UK [6] and about 50 years ago in Germany [7]. Since the 1980s, the trend has been increasingly toward dry stacking to reduce the potential for leakage of caustic liquor to the surrounding environment, reduce the land area required, and maximize the recoveries of soda and alumina. Considerable work was undertaken in Jamaica using the Robinsky [8] sloped thickened tailing disposal system and Ewarton adopted the practice in the mid-1980s [9], see Fig. 5. Additionally, improved methods for thickening and washing of the residues prior to storage, and recovery of decant water during storage, have been developed to increase the recovery of valuable soda and alumina to the Bayer process plants and to minimize the potential for leakage to the surrounding environment.

The current trend in residue storage practice is toward increasing use of dry stacking as the preferred technology, and further research to optimize this technology is appropriate. Many plants now use equipment such as Amphirols to aid dewatering of the mud in order to compact and consolidate the residue, see Fig. 6. Partial neutralization using seawater is practised at a number of Australian plants



Fig. 5 Mud dewatering and compaction, Ewarton, Jamaica close to the sea (Yarwun and QAL); carbonation using waste carbon dioxide from ammonia production has been used-Kwinana (Australia); and accelerated carbonation using intensive farming methods, Aughinish (Ireland), Kwinana, Worsley (Australia) is showing considerable benefits.

Filtration using drum filters and plate and frame filter presses to recover caustic soda produces a lower moisture and more handleable bauxite residue have been employed for some 80 years and is now growing in usage. Plate and frame filter presses were adopted in Vaudreuil in 1936 when the plant was constructed and in Burntisland in 1941 as the lagoons adjacent to the site were full. In the case of Burntisland, the bauxite residue needed to be transported on public roads through the town to a nearby old oil shale mine so a high solids content mud was a key requirement. In the mid 1960s at Ludwigshafen, vacuum drum filters were adopted. Figure 7 shows a typical press filter used for bauxite residue.

In addition to helping recover more caustic, this trend opens up considerable benefits in terms of reuse as the material is normally produced as a friable cake, with typically less than $28 \%$ moisture, and lower soda thereby dramatically reducing transport issues and costs. Alunorte (Brazil), Distomon (Greece), Gardanne, Kwinana, Seydisehir (Turkey), and many plants in China have already adopted or planned to adopt plate and frame filter presses. Hyper Baric filters are reported to achieve particularly lowmoisture content material with the performance of the press being enhanced when steam is used; moisture contents lower than $25 \%$ have been reported [10].

The appalling and tragic incident at the bauxite residue ponds adjacent to the Ajka alumina refinery in Hungary in October 2010 when some $600,000-800,000 \mathrm{~m}^{3}$ of caustic red mud slurry inundated the village of Kolontar and

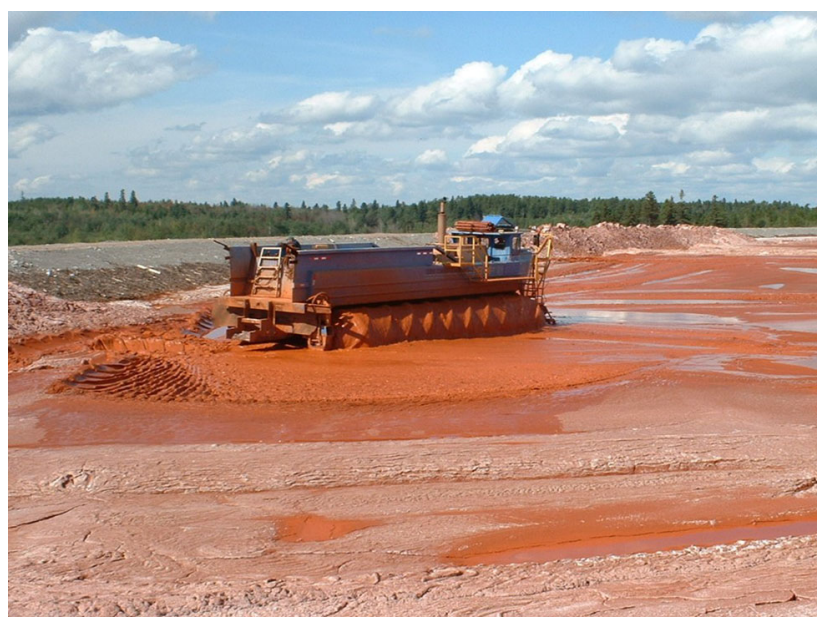

Fig. 6 Dry mud stacking 


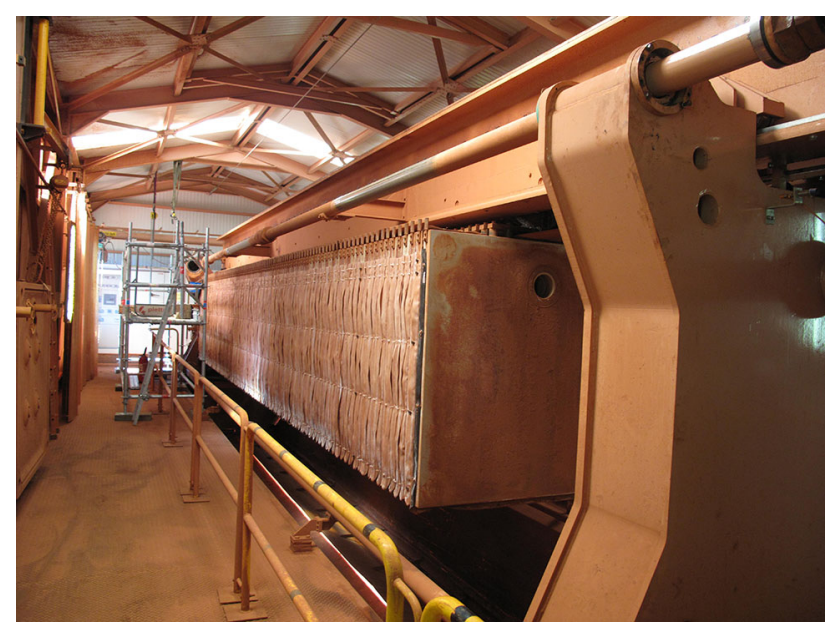

Fig. 7 Plate and filter press, Gardanne, France

flowed into the Torna Creek, Marcal, and Raba rivers had a significant effect on the alumina industry [11]. The producers, via organizations such as European Aluminium and the International Aluminium Institute (IAI), have since worked collaboratively to look for improved solutions and propose best practice guidelines which were published in a guideline document [3]. The IAI continues to encourage collaborative effort on improving storage, monitoring, safety standards, looking at improved remediation techniques, and reuse opportunities and in 2011 issued a set of guidelines for members to work toward [3]. Key messages coming out of the best practice reviews have been the drive to dispose of and store bauxite residue in a safer way with lower caustic and higher solids content. These moves will encourage the utilization of residue as the material produced will be in a more acceptable form for transport, handling, and reuse.

The changes within the industry over the last 20 years has meant than many of the relatively small Bayer plants have ceased operation and there has been an inexorable shift to much larger alumina refineries in countries such as Australia, Brazil, and India. In a number of cases, the former alumina plant has been converted to a specialty alumina plant which uses aluminum hydroxide as feed instead of bauxite; this trend has been particularly apparent in Europe and includes Ajka, Bergheim, Ludwigshafen, Salindres, and Schwandorf. In the USA, the two former Bayer plants at Bauxite have closed but the specialty alumina operation at the former Alcoa plant continues in operation.

Reuse of bauxite residue has for long featured in the thinking of Bayer plant operators but in spite of over a century of endeavor and trials, only some $2-3 \%$ of the 150 million tonnes of bauxite residue produced annually is used in a productive way. Thousands of trials have been successfully completed and dozens of uses have been identified as being technically feasible but the challenge remains to find good economically viable uses for the amount generated every year let alone eat into the material already stockpiled.

The bauxite residue disposal costs for a plant are obviously very dependent on the availability of a suitable disposal site, the distance from the plant to the disposal area and the method of conveying used (by pumping, conveyor or truck). It should be noted that pumping over long distances can be achieved, even in excess of $50 \mathrm{~km}$. Residues from different bauxites vary very much in terms of composition, mineralogy, and particle size as discussed above so behave quite differently. They will have different handling and pumping characteristics and display widely different settling and particle packing characteristics thereby influencing moisture contents after treatment and handling costs. The variation in composition naturally has an overriding effect on potential applications so any practical work looking at applications must take into account the specific chemical composition, mineralogy, $\mathrm{pH}$, particle size distribution, morphology, and nature of the residue emanating from a particular plant.

There is relatively little published data on the cost of disposal of bauxite residue but it is generally estimated to be between 1 and $3 \%$ of the total production cost. The operating cost is perhaps US\$4 to $12 / \mathrm{t}$; the costs for eventual site remediation are very variable and can be quite low if the area is remediated by the addition of just gypsum and manure but can rise considerably if a substantial capping thickness is required and/or there are complex ongoing water management issues. The management and remediation costs are obviously an important factor when potential reuse options are considered. Corporate attitudes have change dramatically over the past 10 years, reflecting growing community awareness and to meet the demands of concerned shareholders and NGOs, and producers now have a more holistic attitude to resolving the problem, finding uses and reducing the area given over to residue disposal/storage.

\section{Developments in Remediation}

As more and more plants close and bauxite residue areas become full, there is growing interest in remediating and rehabilitating residue disposal areas. In some cases, these sites have been left and allowed to colonize by wind and animal-dispersed plant species, in others, caps of various types and thickness have been used, while in others efforts have been made to achieve rehabilitation by the addition of minerals such as gypsum and convert the residue into a medium suitable for sustaining plant growth.

Rehabilitation by capping has been very effectively carried out at closed residue sites in Scotland, France and 
Germany; the type and thickness of the caps has been driven by national legislation, the availability of suitable capping materials, and final intended use.

There are instances when suitable capping materials, especially topsoil are not readily available and other approaches have been used. One particularly effective such rehabilitation project has been carried out using gypsum and manure additions at some former Rio Tinto Alcan owned residue sites in Kirkvine, Jamaica [12]. Very successful rehabilitation trials have been carried out by the University of Limerick and Rusal at the alumina refinery in Aughinish in Ireland which also used gypsum additions to bauxite residue $[13,14]$.

\section{Soil Less Remediation Experience in Jamaica}

At the Kirkvine alumina plant site in Jamaica the bauxite residue had been deposited in former depressions left after bauxite mining and were all within six kilometers of the plant site. Initially, the top soil covering the bauxite mines was used to cap the closed ponds but after a number of the residue ponds had been closed in this way it was accepted that using this topsoil was wasteful and trials were undertaken to rehabilitate the ponds without the addition of any soil or capping material [12].

Typically, bauxite residue slurry from Kirkvine, had a solids content of approximately $18-20 \%$ and when discharged the $\mathrm{pH}$ of the associated liquor in the pond would have been $>13$ but over a period of $30-40$ years, the pond liquor had fallen to less than 11 .

In the mid 1990s, trials on a pond where bauxite residue disposal had just stopped and after conditioning the mud with various pieces of earth moving equipment the areas were treated with gypsum loadings of between 10 and 100 t/ha [15]. Soil electrical conductivity measurements showed levels of gypsum addition between 30 and 40 t/ha gave good results. Poultry manure was then added and seeding was carried using the following mixture of seeds: Cynodon dactylon (Bermuda Grass), Brachiaria decumbens (Brachiaria), Leucaena leucocephala (Leucaena), Ricinus communis (Castor Bean), and Haematoxylum campechianum (Logwood). A vegetation review was undertaken by the University of West Indies in 2011 on the site and some 56 plant species were encountered, which is a composition comparable to a 'dry limestone forest' in Jamaica [16].

The promising results of the topsoil-free method in the trials encouraged Rio Tinto Alcan in 2006 to adopt a similar method on the remaining six ponds which still comprised bare bauxite residue. A major reason for using the method was the acute shortage of topsoil in the area so it was illogical from a sustainability viewpoint to utilize scarce good-quality topsoil for remediating contaminated land. There was a slight modification of the seed mix with the inclusion of Bonavista Beans and African Star Grass.

The plant growth development on the pond from 2007, when the bare residue was still apparent, to autumn 2015 can be seen in the following series of photographs, Figs. 8, 9, 10 , and 11 .

As can be seen from the photographs, the original bare bauxite residue had changed to a reasonably well-covered green area after 3 years and a luxuriant green area after 5 years. An inventory of species growing on one of these pond in 2011 by the University of West Indies found the most abundant species was the Leucaena, ranging from seedlings to trees over $4 \mathrm{~m}$ high together with 14 other plant species identified. By 2015, the Leucaena was over $7 \mathrm{~m}$ high. A survey in 2015 on one of the rehabilitated ponds identified: 26 bird species; 2 lizard species; 2 species of frogs; 35 species of butterflies; 12 species of moths; 3 species of spiders; 2 species of snails; together with 2 species of mammals.

\section{Technical Successes in the Use of Bauxite Residue}

Many potential applications have been considered with particular focus on routes focusing on the recovery of elements present in the bauxite residue. Even Bayer himself in his 1892 patent describing the Bayer Process proposed the potential for iron recovery: stating, "The red, iron containing residue after digestion settles well and, with sufficient practice, can be filtered and washed. Due to its high iron and aluminium oxide content, it can be, in an appropriate manner, treated or with other iron ores, be smelted to iron."

Possible applications can broadly be broken down into various categories:

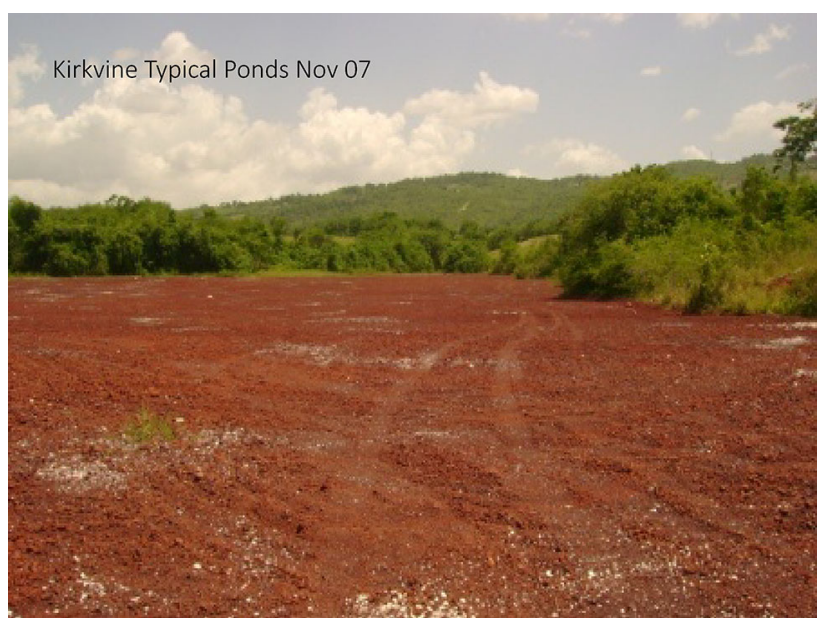

Fig. 8 Kirkvine, Jamaica bauxite residue pond November 2007 


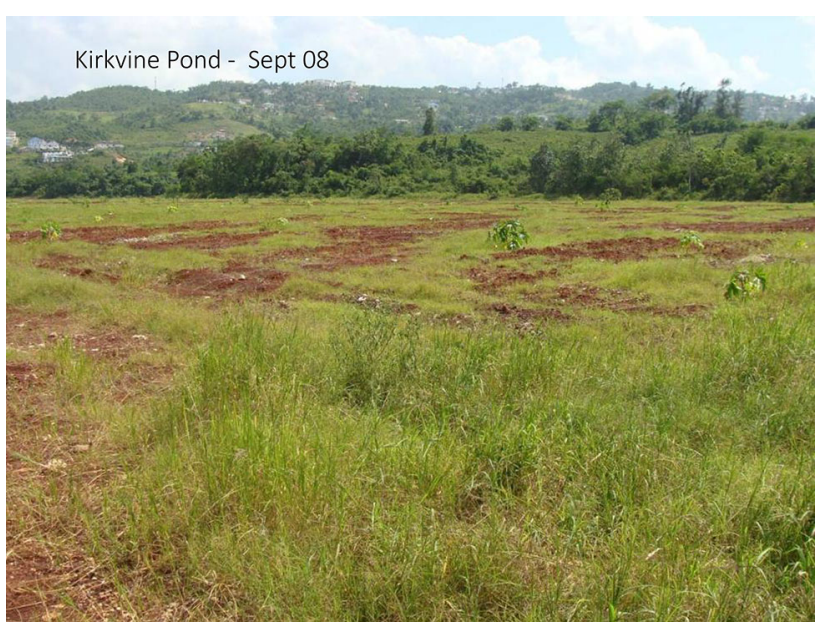

Fig. 9 Kirkvine, Jamaica bauxite residue pond September 2008

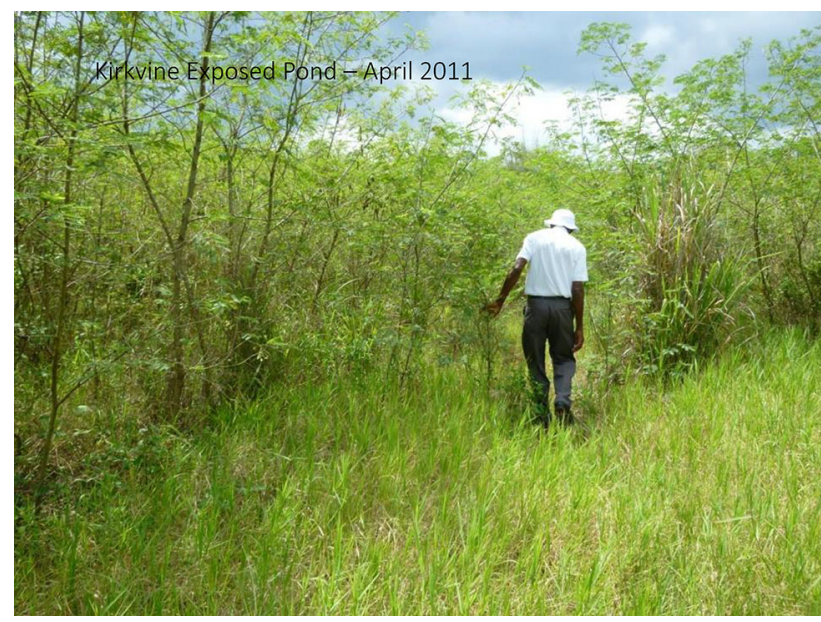

Fig. 10 Kirkvine, Jamaica bauxite residue pond April 2011

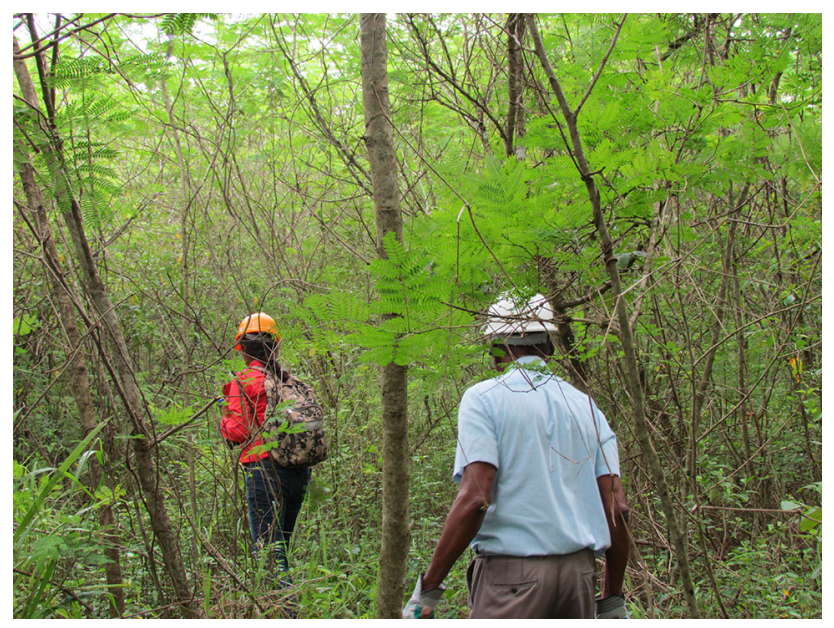

Fig. 11 Kirkvine, Jamaica bauxite residue pond September 2015
- recovery of specific components present in the bauxite residue, e.g., iron, titanium, aluminum, lanthanides, scandium, yttrium, and gallium $[17,18]$;

- $\quad$ use as a major component in the manufacture of another product, e.g., cement [19-21];

- use of the bauxite residue as a component in a building or construction material, e.g., concrete, tiles, bricks [22];

- use for specific properties, e.g., soil amelioration or landfill capping [22];

- conversion of the bauxite residue to a useful material by modifying the compounds present, e.g., Virotec process [23-25].

The list of applications where bauxite residue has been evaluated and trialled covers almost all of inorganic material science and seeking effective solutions has attracted many researchers from industry, universities, institutes, and entrepreneurs [17-59]. Some of the most attractive areas have been: cement manufacture [19-21, 28], use in concrete, iron recovery [30, 34], titanium recovery [17], use in building panels, bricks, foamed insulating bricks, tiles, soil amelioration, refuse tip capping/site restoration, treatment of acid mine drainage [2325], soil amelioration, road construction [27], dam/levee construction, pigments, and glass ceramics. Meanwhile, some other uses which have been shown to be technically feasible but not yet exploited to any significant degree are lanthanides (rare earth elements) recovery, scandium recovery, gallium recovery, vanadium recovery, cobalt recovery, yttrium recovery, adsorbent of heavy metals/ dyes/phosphate/fluoride, water treatment chemical, ceramics, foamed glass, oil drilling or gas extraction proppants, gravel/railway ballast, calcium and silicon fertilizer, filler for PVC, wood substitute, geopolymers [45], catalysts [40], plasma spray coating of aluminum and copper, manufacture of aluminum titanate-Mullite composites for high temperature-resistant coatings, composites with epoxides, composites with poly aniline, manufacture of radiopaque materials for the construction of X-ray diagnostic and CT scanner rooms, catalyst for hydrocarbon cracking, desulfurisation of flue gas, arsenic removal, and chromium removal. Some applications, such as use in pigments have been successful but use very small tonnages.

The question so often asked is why some of these potentially exciting applications have failed to be implemented or exploited when on a small scale they look so attractive. It is certainly not the desire of producers to harbor their bauxite residue! 
At various times, targets have been proposed for reuse of bauxite residue: IAI Alumina Technology Roadmap strategic goal of $20 \%$ by 2025; Chinese Government target of $25 \%$ reuse by 2015; Shandong Province target of $40 \%$ reuse by 2015 . This compares to an estimated reuse level in China of $10 \%$ and globally $2-3 \%$.

\section{Major Barriers to Reuse}

When considering the commercial/industrial implementation of uses that have been found to be technically successful, it is important to consider the barriers that have prevented the implementation of apparently sound and economic solutions. The materials that bauxite residue would be replacing in any application are very often readily and cheaply available so any negative feature or minor impediment is potential barrier to change. Assessing both the actual risk, and the perceived risk to the stakeholders for any particular application is crucial. Some important risk factors to consider are discussed below.

\section{Leaching of Heavy Metals}

The leaching of metals, especially heavy metals, into the environment is a particular issue for any material that is used in building products, bricks, roads, in construction, soil capping, or soil amelioration. Soluble chromium is normally the element of most concern though arsenic can also be a problem for some specific residues. This is generally only an issue when the materials are exposed to a particularly high or particularly low $\mathrm{pH}$ values. Solubility/ extraction tests of components or aggregates (for example EN 12457-Waste Acceptance Criteria Testing) or metal uptake studies in vegetation may all be necessary depending on the application in order to show that the bauxite residue will not be a problem in use.

Possible concerns over liability of contaminating surrounding land may be a particular issue if the product is used in some way where the leachate from the building, structure, aggregate, etc., could leach into a water course.

\section{Radioactivity}

Most bauxites will contain low levels of radioactive elements, termed NORM (naturally occurring radioactivity material) in particular ${ }^{238} \mathrm{U}$ and ${ }^{232} \mathrm{Th}$, and this is normally doubled in the bauxite residue. The radioactivity in the bauxite residue is sometimes referred to as TENORM (technologically enhanced naturally occurring radioactivity material).

In general, two approaches are used to assess the risk from radioactivity: measurement of the elements that could lead to radioactivity, namely analyzing for Ac, At, Bi, Pa,
$\mathrm{Pb}, \mathrm{Po}, \mathrm{Ra}, \mathrm{Th}, \mathrm{Tl}, \mathrm{U}$ and then calculating a radioactivity value; or by direct measurement. The EU Radiation Protection Guideline 112 has a recommended range of 0.3-1 mSv/y for building materials; the particular limit being determined by the expected exposure.

The data published on radioactivity levels have historically been limited but some information that has been reported on a range of bauxite residue shows that thorium was only present in significant levels in bauxite residue from Venezuelan bauxite but still remains below acceptable limits [48-50]. The uranium content is over $10 \mathrm{mg} / \mathrm{kg}$ in Jamaican and Venezuelan bauxites but the total radioactivity calculated will still remain below legislative limits in bauxite residue. Some of the uranium does dissolve in the Bayer process but it subsequently re-precipitates and is associated with the coarser bauxite residue fraction. Meanwhile, thorium is not affected by low-temperature extraction process and is most often associated with the fine bauxite residue fraction.

The IAEA (International Atomic Energy Authority) Basic Safety Guide for marketable materials sets a limit of $1 \mathrm{~Bq} / \mathrm{g}$ per radionuclide; for uranium this is equivalent to $81 \mathrm{mg} / \mathrm{kg}$. From the published data for bauxite residue, this level does not representative a problem for bauxite residues although it should be noted that the level measured for ${ }^{238} \mathrm{U}$ and ${ }^{232} \mathrm{Th}$ on bauxite residue from the closed Jamaican alumina plant at Moggetty was 0.97 and $0.32 \mathrm{~Bq} / \mathrm{g}$ [49]. The values generally present in local soil for ${ }^{238} \mathrm{U}$ and ${ }^{232} \mathrm{Th}$ were 0.22 and $0.037 \mathrm{~Bq} / \mathrm{g}$, respectively.

A thorough understanding of the radioactivity issues are most important when any application is considered. Public perception and concerns must be addressed as despite the data shown above, the radioactivity levels measured have stopped a number of interesting applications proceeding. Examples include the manufacture of bricks for domestic buildings in Jamaica [49], the use of construction materials in applications other than roof tiles in Hungary, and the manufacture of ceramic insulating fiber for domestic situations. An "Activity Index" assessment has been proposed to consider each application on its merits looking at the level of radioactivity in the bauxite residue, the amount of bauxite residue in the product, and the time and degree of expected exposure [50].

\section{Alkalinity/High Sodium}

The high $\mathrm{pH}$ is a problem from both a health and safety aspect and potentially adverse effects in the particular application. This ranges from poor weathering resistance in construction materials to high sodicity when used in soil amelioration. Both high sodium levels and high $\mathrm{pH}$ will be reduced when press filters are used. Accelerating carbonation by the use of carbon dioxide, intensive farming, or acid neutralization as a first stage could also be considered to reduce the $\mathrm{pH}$. 


\section{Hazardous Rating of Bauxite Residue in Some Jurisdictions}

There have been many discussions, particularly in the EU, concerning the hazardous nature of bauxite residue in particular with respect of its $\mathrm{pH}$. If classified as a hazardous waste, this will add considerably to the cost of all aspects of handling, storage, and transport. Based on a number of standard test criteria, any waste material with a $\mathrm{pH}$ value above 11.5 is often considered hazardous. Implementation of an improved filtering operation, may reduce the $\mathrm{pH}$ of bauxite residue to a level that avoids skin and eye irritation.

\section{Moisture Level}

A high moisture level will add to transport costs and will be an issue if energy has to be expended in driving it off in drying or firing (calcination), so it is advantageous for the bauxite residue to have as high a solids content as possible. Additives such as starch have been used for dewatering for very many decades but from the 1980 s there was growing use of synthetic flocculants. The use of plate and frame press filters goes back a very long period and was certainly being used in the 1930s. It then seems to have fallen out of favor and rotary drum filters became more common. Now there is a trend back to the use of plate and frame press filters being adopted to reduce water content which can yield a moisture level of $26 / 27 \%$ or lower.

\section{Transport Costs}

The logistics cost is very substantially increased if the material is classified as hazardous since special procedures must be implemented during transportation. While the high alkalinity does not impose a problem with corrosion of steel, it does cause pitting of aluminum which is a part of the UN transport code. If the conversion or use is not carried out at the alumina refinery, the bauxite residue will almost certainly be competing with some other low cost ore, mineral or waste-reducing the transport costs to as low as possible is therefore essential. All mitigating operations should be considered, e.g., pumping the bauxite residue to some other area and processing it, dewatering methods/aids, and solar drying.

A major trend since the 1980s has been the closure of small and medium-sized alumina plants, perhaps $100,000-300,000 \mathrm{t} / \mathrm{y}$ annual production, in Europe and the growth of much larger plants, this is especially true in Brazil and Australia. The largest ones can produce over 6 million tonnes per year of alumina. These larger plants are very often remote from large centers of population which is likely to mean there is a lower level of industrial activity and consequently limit some opportunities for the use of bauxite residue. This makes the transport cost issue even more critical when considering uses.

\section{Industrial Scale Successes}

It is generally estimated that some $2-4.5$ million tonnes of the bauxite residue produced annually is used in some way although reliable data are difficult to obtain as it does fluctuate markedly from year to year as the economics change and some uses are internal such as road and dyke construction within a particular alumina refinery.

Current annual estimates collected from various sources are

- Cement-500,000 to $1,500,000$ tonnes;

- Raw material/additive in iron and steel production200,000-1,500,000 tonnes;

- Roads (see Fig. 12)/landfill capping (see Fig. 13)/soil amelioration-200,000-500,000 tonnes;

- Construction materials (bricks (see Fig. 14), tiles, ceramics, etc.) -100,000-300,000 tonnes;

- Other (refractory, adsorbent, acid mine drainage (Virotec), catalyst, etc.)—300,000 tonnes.

- Based on the above data, this gives a total of approximately 2.4-4.1 million tonnes per year.

\section{Cement}

Bauxite residue can provide valuable iron and alumina values in the production of Ordinary Portland cement clinker and it has the added benefit of substantially reducing the carbon dioxide emissions during production. In addition, it can behave as a supplementary cementitious



Fig. 12 Use of Red Sand ${ }^{\mathrm{TM}}$ for road construction (Photograph courtesy of Alcoa) 


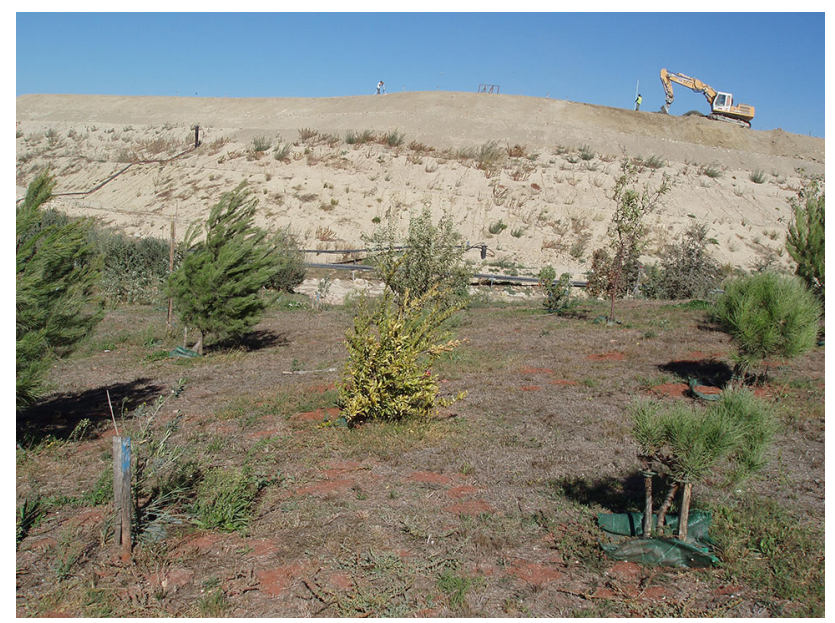

Fig. 13 Use of Bauxaline ${ }^{\circledR}$ in landfill capping in Provence

material which is used in mortar or concrete mixes, this can provide: better mechanical properties; more efficient use of resources; lower carbon dioxide emissions [19-21].

Certain types of 'special' cement, for example, calcium sulfo-aluminate (belite type cement), can also be made utilizing bauxite residue, these generate very substantially lower carbon dioxide emission levels during production [28].

Excluding China, the use of bauxite residue in the cement industry in the manufacture of clinker is estimated at approximately $260,000 \mathrm{t} / \mathrm{y}$ almost all of which is from the Nikolayev alumina plant in the Ukraine. The bauxite residue from Nikolayev is used in cement plants in the Ukraine, Russia, Georgia, Moldova, and Belarus. The Nikolayev refinery blends the residue produced to give the cement plant a consistent feed and the climate allows a reasonably low moisture product to be produced. There is modest usage of bauxite residue from AdG's plant in

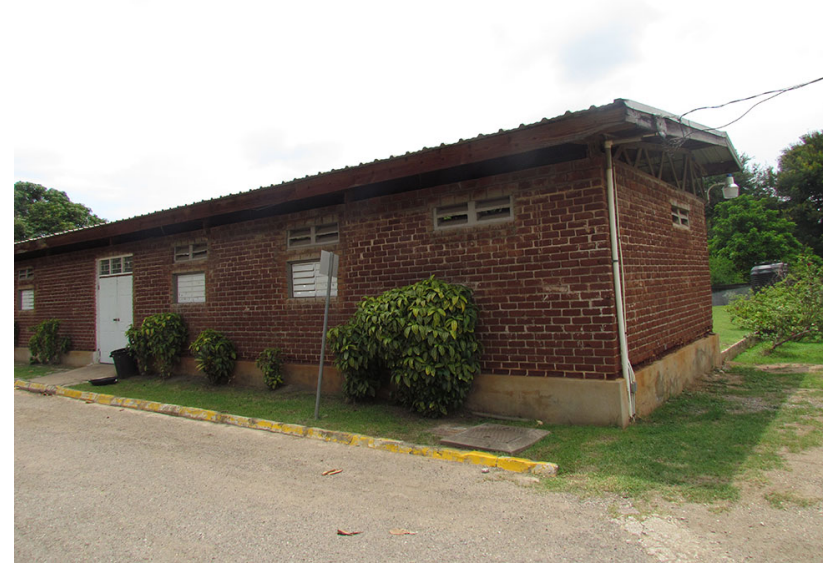

Fig. 14 Use of bauxite residue in bricks, JBI, Jamaica
Distomon in cement production at a plant in Patras; further usage is restricted by the lack of dry storage. Much larger usage, up to $180,000 \mathrm{t} / \mathrm{y}$ was anticipated at a cement plant in Milaki but changing economic circumstances have put increased usage on hold. There has also been some historical usage of bauxite residue from the refinery in Tulcea in a local Romanian cement plant and also reportedly small-scale usage of bauxite residue from the Gandja alumina refinery in Azerbaijan in cement. The use of bauxite residue in cement in China was formerly several million tonnes a year [46, 47] but this has fallen because of the changes in construction industry standards and also a reduction in the number of plants operating a sinter or Bayer-sinter extraction route. It should be noted that the bauxite residue produced from the sinter or Bayer-sinter extraction route is very different chemically from that produced in a conventional Bayer alumina plant.

\section{Iron and Steel}

The usage of bauxite residue in steel manufacture is of the order of 70,000-100,000 tonne/year, excluding China. The iron ores that are normally used in iron and steel manufacture have an iron content of typically $55-70 \%$ with $66 \%$ being available from many good-quality sources. Meanwhile, for comparison, bauxite residues have a typical range of iron of $3-42 \%$. It is important to consider these contents and realize the difficulty in even closely matching the economics against using virgin iron ore, especially at the current price of iron ore. Some success has been achieved in China, particularly in plants in Southern China where the bauxite residue can have an iron content of up to $42 \%$. Notably, success has also been achieved using magnetic separation techniques as a first stage of processing to concentrate the iron fraction. The bauxite residue material is also wet and has a high sodium content which is a disadvantage in steel production. Recent research in Russia using low alkaline bauxite residue and bentonite has been very effective in raising the iron content, improving agglomeration quality and thereby giving greater yields in the production of iron ore pellets [51].

\section{Metals Recovery}

The simultaneous recovery of other metals, for example, titanium and aluminum, would improve the economics of using bauxite residue for iron recovery in steel production. The only non-Chinese plant using bauxite residue for making steel is based in the Urals. The work on iron extraction from bauxite residue in the Southern Chinese alumina plants is discussed later. Several Indian sources of bauxite residue are relatively high in iron, between 30 and $39 \%$, and a considerable amount of work has been done to 
recover the iron values in the bauxite residue from the NALCO plant using the Romelt process but while technically feasible, it was uneconomic because of the high-energy costs involved in the process.

\section{China}

China is worth discussing separately as it devoting a very considerable effort into searching for and implementing reuse of bauxite residue, much of it being driven by Chinese Government initiatives [41-43, 46, 47]. China has shown the most dramatic change in the last 15 years with alumina production increasing from about 2.5 million tonnes in 2000 to almost 59 million tonnes by 2015 [1]; the generation of bauxite residue has grown to some 60 million tonnes a year. The alumina manufacturing routes have historically been very different because of the nature of the indigenous bauxite. Sinter routes or combined Bayer-sinter routes were widespread but are now declining sharply, except for the production of chemical grade aluminas, and the industry has become more dependent on imported bauxites. This change in route has significantly changed the characteristics and composition of the bauxite residues being produced. Hitherto much of the imported bauxite was from Indonesia and Australia but curtailment of bauxite exports from Indonesia is changing the nature of the bauxite residue yet again. Traditionally, the alumina plants in the Northern part of China produced a residue very high in calcium and silicon oxides but low in iron oxide making them suitable for cement production while those in the south of China have a residue high in iron which makes the recovery of iron the most likely option for them to pursue. In 1965, a cement plant was built to consume residue from Shandong Alumina and by the late 1990s over 6 million tonnes of residue were used to make OPC and oil well cements. However, new standards for cement were introduced which restricted sodium level content and the progressive move to imported bauxites led to a reduction in the amount going into cement.

A very strong driving force in China has been government imposed legislation requiring that bauxite residue is reused. Since 2005 very large-scale effort to utilize more bauxite residue in many areas with the main effort being devoted to high-intensity magnetic separation to concentrate iron; glass ceramics $\mathrm{CaO}-\mathrm{SiO}_{2}-\mathrm{Al}_{2} \mathrm{O}_{3}$; bricks (with lime fly ash); and polymer fillers.

The manufacture of bricks, tiles, and other building materials has been shown to be technically possible by many groups of workers from a wide variety of sources of bauxite residue using both fired and chemically bonded methods. Outside China, however, while plants have started up, production has not continued.

\section{Landfill Capping}

Use of bauxite residue for capping municipal landfills is carried out in France and has been trialled in the USA. Landfill capping trials have been successfully carried out in Louisiana with Cajunite ${ }^{\mathrm{TM}}$ where the bauxite residue product was found to have advantages over natural clay. The amounts used in France has varied considerably from year to year but is estimated to be between 40,000 and 100,000 tonne/year. It can only be undertaken within a relatively small radius of each refinery depending on local transport costs and the availability of other covering/capping materials; the maximum distance that the residue can effectively be transported for this application is estimated to be about $75 \mathrm{~km}$. Municipalities will normally wait until an entire site is full before remediating/capping it, hence the wide variation in usage between years. The bauxite residue must be in a form that can safely and readily be carried in trucks on public roads. Possible concerns are dust from the bauxite residue when dry and heavy metal leaching characteristics.

Somewhat related has been the use as a soil amendment/conditioner for acidic/sandy soils; on large-scale trials, this has been shown to be safe and beneficial, especially in controlling high levels of phosphorous. However, controversy over two decades has prevented its implementation until recently.

\section{Roads}

Usage for road building and dyke/levee construction is estimated at 20,000 tonne/year, however, it is difficult to gain an accurate figure as some of the bauxite residue is used internally within each alumina site complex, often for roads within the bauxite disposal area. A considerable about of work has been done in Western Australia by Alcoa in conjunction with Curtin University on using Red Sand ${ }^{\mathrm{TM}}$ in the construction of roads [27]. In this process, the coarse sandy fraction of the bauxite residue is neutralized with carbon dioxide to create the Red Sand ${ }^{\mathrm{TM}}$ or ReadyGrit $^{\mathrm{TM}}$. The target is to replace virgin sand and crushed limestone for sub-grade and top dressing: for each cubic meter of virgin sand replaced there are savings of 4.4 and $2.7 \mathrm{MJ}$, respectively, in energy conservation. The benefits include lower carbon footprint; reduced loss of vegetation as it avoids use of quarries; cost savings; less water usage; and reduced eutrophication.

\section{Recent Developments}

The global desire for the more efficient use of resources has led to a greatly increased effort looking at uses of bauxite residue over the past 3 years. Increased enthusiasm from 
industry, more university activities and the input of funds from organizations such as the EU has led to greater cooperation between industries and academia.

In 2015, under the Horizon 2020 initiative, the EU agreed to fund $15 \mathrm{PhD}$ students to work on the recovery of materials and the utilization of bauxite residue. Some Euro 3.7 million was set aside for this European Training Network for Zero-Waste Valorisation of Bauxite Residue (REDMUD) project. The work is focussing on the extraction of iron, aluminum, titanium and rare earth elements (including scandium) as well as the production of new building materials [52].

A European Innovation Partnership has been formed to explore options for using by-products from the aluminum industry, BRAVO (Bauxite Residue and Aluminium Valorisation Operations). This seeks to bring together industry with researchers and stakeholders to explore the best available technologies to recover critical raw materials.

\section{Materials Recovery}

The strongly growing demand for rare earth elements (REEs), and the concentration of production in China has led to a renewed interest in the extraction of REEs from bauxite residue [18, 53-58]. The REEs, normally taken to mean the lanthanides plus scandium and yttrium, are essential constituents of modern permanent magnets, nickel metal hydride batteries, and lamp phosphors with dramatic growth driven by increasing demand for electric and hybrid cars, wind turbines, and compact fluorescent lights. The very strong demand for scandium is driven by its emerging use in aluminum alloys where its ability to control grain size leads to exceptionally high strength but light components. These REEs are normally divided into the light rare earth elements (LREE) covering the elements from lanthanum to samarium and the heavy rare earth elements (HREE) covering europium to lutetium. Studies on the REEs in bauxite has been pursued for many years and was extensive investigated during the 1970s in Italy: REEs are also found in bauxites from Olmedo in Sardinia, Vlasenica in Bosnia Herzegovina, Grebnik in Kosovo, and PanassosGhiona, Marmara, Evia Island in Greece.

During the Bayer process, the REEs remain undissolved so are concentrated up in the resulting residue. Much work was done during the 1980s on Jamaican bauxite residues using dilute acid as the first stage leaving behind the iron and titanium oxides, the REEs were then recovered by selective precipitation [18], but many new projects have started in recent years. These include a joint venture between the Jamaican Bauxite Institute and Nippon Light Metals to construct a pilot plant for extraction from locally arising bauxite residues [53]. A particular focus of the
ETN-MSCA REDMUD programme is the recovery of REEs and scandium. Examples include selective leaching after sulfation roasting at KU Leuven [54], and use of cation exchange chromatographic techniques at the National Technical University of Athens [55]. The British Geological Study and Camborne School of Mines have recently reviewed the potential for REEs in European bauxite residues [56]. Assuming a total REE content of $1000 \mathrm{mg} / \mathrm{kg}$ and an extraction efficiency of $50 \%$, then the group estimated that over 200,000 t of REEs could be available from bauxite residue produced in Europe since 1972. In global terms, over $172,000 \mathrm{t}$ of REEs are sent to bauxite residue disposal ponds which compares to some $100,000 \mathrm{t}$ of REEs produced annually.

Orbite Technologies Inc., a Quebec-based materials/ mineral processing company has developed an acid extraction route to recover alumina from aluminous clay and other alumina-containing materials such as fly ash. Using a modification of this route, they have developed and patented the recovery of alumina, titania, iron oxide, magnesia, rare earth elements, and other rare metals from bauxite residue. The initial extractions are carried using $6 \mathrm{M}$ hydrochloric acid at temperatures between 140 and $165{ }^{\circ} \mathrm{C}$ and a pressure of $60-90 \mathrm{psi}$; this is used to extract the aluminum fraction, followed by successive recovery of the other required compounds by modified acid strength and temperature steps [58]. The company is presently focussing on the manufacture of high purity aluminum oxide ( $>99.99 \%$ purity) and is planning to construct a $100,000-200,000 \mathrm{t} / \mathrm{y}$ processing plant to demonstrate the feasibility of the bauxite residue recovery on a larger scale.

\section{Heavy Metal and Phosphate Removal}

The ability of bauxite residues to react with heavy metals, especially from mine and mineralogical processing sites, has been examined by several groups around the world [23-25] so far with only modest tonnages being sold but several new approaches are emerging.

Virotec, a company that originated in Australia based on work done by David McConchie at Southern Cross University, has widely promoted a product called Bauxsol ${ }^{\circledR}$ since about 2002 for the remediation of contaminated sites and the adsorption of heavy metals particularly from acid mine drainage. Bauxsol ${ }^{\circledR}$ is manufactured by reacting brines with bauxite residue to produce a partially neutralized material; the magnesium to calcium ratio is critical to obtain good heavy metal adsorption; the neutralization process is called Basecon ${ }^{\circledR}$.

In Italy, using residues from the Eurallumina plant, good heavy metal absorption results were obtained by neutralizing the material with seawater. In some formulations, the 
bauxite residue was mixed with fly ash which improved the absorption of arsenic.

In Korea, work showed how pellets made by heat treating at $600{ }^{\circ} \mathrm{C}$, mixtures of bauxite residue, polypropylene, sodium metasilicate, magnesium chloride, and fly ash had good heavy metal absorption, especially lead, copper, and cadmium.

Work on bauxite residue from San Ciprian mixed with gypsum was found to have a good capability to remove copper, zinc, nickel, and cadmium from waste streams.

Work at the Chinese Academy of Science has shown good benefits in the use of bauxite residue for the adsorption of lead, cadmium, and copper.

Recent developments in the UK by REDmedia Technologies with their Redmedite has shown particular success in treating contaminated leachate from Wheal Augusta, a former barytes mine in UK. This work was undertaken by Plymouth University who investigated contaminant removal from leachate and remediation of contaminated soil. The percentage of contaminants removed from the leachate was reported to be $\mathrm{Al}-91 \%, \mathrm{As}-65 \%, \mathrm{Cd}-73 \%, \mathrm{Co}-$ $81 \%, \mathrm{Cr}-95 \%, \mathrm{Cu}-99 \%, \mathrm{Fe}-98 \%, \mathrm{Mn}-26 \%, \mathrm{Ni}-$ $28 \%, \mathrm{~Pb}-99 \%$, and $\mathrm{Zn}-74 \%$.

Pellets of Redmedite and Bauxsol ${ }^{\circledR}$ have proved to be very effective at phosphate removal in sewage treatment, and recent improvements in pellet formation are forecast to open up significant tonnages as European regulation on phosphate removal becomes more stringent.

\section{Combination of Wastes to Produce Construction Materials}

A British group of entrepreneurs, Purgo Limited, has developed an innovative approach using bauxite residue in combination with different waste materials in an unconventional way to manufacture construction materials such as building panels, bricks, tiles, and aggregates. A particular merit of the approach is the ability to very substantially minimize the likely leaching of the heavy metal contaminants such as arsenic, cadmium, chromium, lead, mercury, molybdenum, and selenium. Bauxite residue samples treated via the process are able to meet the 'inert' classification as defined in the Waste Acceptance Criteria Testing standard BS EN 12457 [59].

\section{Summary}

The early history of bauxite residue disposal and storage involved using estuaries or land impoundment areas adjacent to the factory. Disposal into rivers, estuaries, or the sea became common for a number of years but this has now totally ceased. Storage of bauxite residue as a dilute slurry in old mines, impounded areas, or dammed valleys was widely practised until the mid-1980s but since then there has been a growing trend to higher solids storage method. More recently, filter presses to produce an even higher solids residue have become increasing common. Innovative approaches to the rehabilitation of former residue sites without capping have proved very successful in certain situations and could prove beneficial for other closed residue sites in the future. In many ways, it is discouraging that despite so much work over the last century only some 2-3\% of the 150 million tonnes of bauxite residue produced annually is used in a productive way. Some of the applications have been economically attractive for a number of years and then factors have changed which renders them no longer economically viable. However, it is vital to consider how changes in process technology or demand requirements over time means that ideas previously considered not worth exploiting can become viable and commercially attractive. From the process side, improvements include the increasing use of press filters which will result in residues with lower moisture levels, lower soda levels, lower contaminants, lower $\mathrm{pH}$ levels, and the higher efficiency electro-magnets that are now available allows for more effective iron recovery from bauxite residue. Meanwhile, the growing demand for scandium in aluminum alloys or the demand for particular rare earth elements also present new opportunities. In addition, public, corporate, and government attitudes have never presented such an encouraging environment for developing and implementing bauxite residue uses.

Acknowledgments Thanks are due to Katy Tsesmelis of World Aluminium and György (George) Bánvölgyi for very helpful comments on the manuscript.

\section{References}

1. Data published annually by World Aluminium, www.world-alu minium.org

2. European Aluminium Association (EAA) (2013) Environmental profile report for the European aluminium industry-life cycle inventory data for aluminium production and transformation processes in Europe. http://www.alueurope.eu/wp-content/uploads/ 2011/10/Environmental-Profile-Report-for-the-European-AluminiumIndustry-April-2013.pdf

3. World Aluminium and the European Aluminium Association "Bauxite Residue Management: Best Practice", available from the International Aluminium Institute, 10 King Charles II Street, London, SW1Y 4AA, UK and on line from http://bauxite.worldaluminium.org/refining/bauxite-residue-management.html

4. Feret F (2013) Selected applications of Rietveld-XRD analysis for raw materials of the aluminium industry. JCPDS-International Centre for Diffraction Data

5. Evans K, Nordheim E, Tsesmelis K (2012) Bauxite residue management. In: Suarez CE (ed) Light Metals 2012, John Wiley \& Sons, Hoboken, NJ, pp 63-66 
6. Purnell BG (1986) Mud disposal at the burntisland alumina plant. In: Miller RE (ed) Light Metals 1986, TMS, Warrendale, PA, pp. 157-159

7. Pohland HH, Tielens AJ (1986) Design and operation on nondecanted red mud ponds in Ludwigshafen. In: Proc. Int. Conf. Bauxite Tailings, Kingston, Jamaica

8. Robinsky EI (1985) Current Status of the Sloped Thickened Tailings Disposal System. Proc. Int. Conf. Bauxite Tailings, Kingston, Jamaica

9. Chandler JL (1986) The stacking and solar drying process for disposal of bauxite tailings in Jamaica. In: Proc. Int. Conf. Bauxite Tailings, Kingston, Jamaica

10. Bott R, Langeloh T (2015) Process options for the filtration and washing of bauxite residue. Bauxite Residue Valorization Conference, Leuven, pp. 62-70

11. Mayes W, Burke I (2015) Risks, remediation and recovery: lessons for bauxite residue management from Ajka. Bauxite Residue Valorization Conference, Leuven, pp. 35-45

12. Lyew-Ayee PA, Persaud SD, Evans KA, and Tapp RG (2011) From red to green - a regulators and company partnership in bauxite residue remediation. ICSOBA Seminar on Bauxite Residue, 2011, Travaux ICSOBA 36(40): 137-145

13. Courtney RG, Mullen G, Harrington T (2009) An evaluation of revegetating success on bauxite residue. Restor Ecol 17(3):350-358

14. Courtney, RG, Harrington T (2011) Revegetation strategies for bauxite residue: a case study of Aughinish, Alumina, Ireland. ICSOBA Seminar on Bauxite Residue, Travaux ICSOBA 36(40): $146-153$

15. O'Callaghan WB, McDaniel SC, Richards DM, Reid RE (1999) Development of a Topsoil-Free Vegetative Cover on a Former Red Mud Disposal Site. Alcan Jamaica Company

16. Webber D, Rose P, Azan S, Doctor L (2005) Vegetation Inventory of Kirkvine Pond 6. Department of Life Sciences, University of the West Indies

17. Erca E, Apak R (1999) Furnace smelting and extractive metallurgy of red mud: recovery of $\mathrm{TiO}_{2}, \mathrm{Al}_{2} \mathrm{O}_{3}$ and pig iron. $\mathrm{J}$ Chem Technol Biotechnol 70(3):241-246

18. Alcan International Limited, United States Patent, USP 5,030,424 (1991)

19. Tsakiridis PE, Agatzini S, Oustadakis LP (2004) Red mud addition in the raw meal for the production of Portland cement clinker. J Hazard Mater B116:103-110

20. Vangelatos I, Angelopoulos GN, Boufounos D (2009) Utilization of ferroalumina as raw material in the production of Ordinary Portland Cement. J Hazard Mater 168:473-478

21. Pontikes Y, Angelopoulos G (2013) Bauxite residue in cement and cementitious applications: current status and a possible way forward. Resour Conserv Recycl 73:53-63

22. Klauber C, Gräfe M, Power G (2011) Bauxite residue issues: II. Options for residue utilization. Hydrometallurgy 108(1):11-32

23. McConchie D, Clark M, Hanahan C, Davies-McConchie F (2000) The use of seawater-neutralised bauxite refinery residues in the management of acid sulphate soils, sulphidic mine tailings and acid mine drainage. In: Gaul K (ed) Proceedings of the 3rd Queensland Environment Conference, Environmental Engineering Society, pp. 201-208

24. McConchie D, F. Davies-McConchie F, Clark M, Fergusson L (2003) The use of industrial mineral additives to enhance the performance of bauxsol-based environmental remediation reagents. Paper presented to Australian Industrial Minerals Conference, Brisbane, Australia

25. Fergusson L, Commercialisation of environmental technologies derived from alumina refinery residues: a ten-year case history of Virotec, Commonwealth Scientific and Industrial Research Organisation (CSIRO), Project ATF-06-3 "Management of
Bauxite Residues", Department of Resources, Energy and Tourism (DRET), Commonwealth Government of Australia, Asia-Pacific Partnership on Clean Development

26. Parekh BK, Goldberger WM, An assessment of technology for the possible utilization of Bayer process muds. Published by the U. S. Environmental Protection Agency, EPA 600/2-76-301

27. Biswas WK, Cooling DJ (2013) Sustainability assessment of Red Sand ${ }^{\mathrm{TM}}$ as a substitute for virgin sand and crushed limestone. J Ind Ecol 17(5):756-762

28. Singh M, Upadhayay SN, Prasad PM (1996) Preparation of special cements from red mud. Waste Manag 8:665-670

29. Agrawal A, Sahu KK, Pandy BD, Kalkan E (2006) Utilization of red mud as a stabilization material for the preparation of clay liners. Eng Geol 87:220-229

30. Paramguru RK, Rath PC, Misra VN (2005) Trends in red mud utilization-a review. Miner Process Extr Metall Rev 26(1):1-29

31. Parlikar UV, Saka PK, Khadilkar SA (2011) Technological options for effective utilization of bauxite residue (Red mud) - a review. International Seminar on Bauxite Residue (RED MUD), Goa, India

32. Shaobin W, Aug HM, Tade MO (2008) Novel applications of red mud as coagulant, adsorbent and catalyst for environmentally benign processes. Chemosphere 72(11):1621-1635

33. Satapathy A, Sutar H, Mishra SC, Sahoo SK (2013) Characterization of plasma sprayed pure red mud coatings: an analysis. Am Chem Sci J 3(2):151-163

34. Guanzhou Q, Liu Y, Jiang T, Hu Y (1995) Influence of coal sort on the direct reduction of high-iron-content red mud. J Central South Univ Technol 2(2):27-31

35. Fofana M, Kmet S, Jakabsk T (1995) Treatment of red mud from alumina production by high-intensity magnetic separation. Magn Electr Sep 6:243-251

36. Agatzini-Leonardou S, Oustadakis P, Tsakiridis PE, Markopoulos C (2008) Titanium leaching from red mud by diluted sulfuric acid at atmospheric pressure. J Hazard Mater 157(2-3):579-586

37. Qinfang X, Xiaohong L, Schlesinger ME, Watson JL (2001) Low temperature reduction of ferric iron in red mud. In: Anjier J (ed) Light Metals 2001, TMS, Warrendale, PA, pp. 157-162

38. Mishra B, Staley A, Kirkpatrick D (2001) Recovery and utilization of iron from red mud. In: Anjier J (ed) Light Metals 2001, TMS, Warrendale, PA, pp. 149-156

39. Mishra B, Staley A, Kirkpatrick D (2002) Recovery of valueadded products from red mud. Miner Metall Process 19(2):87-94

40. Cakici AI, Yanik J, Çar SU, Karayildirim T, Anil H (2004) Utilization of red mud as catalyst in conversion of waste oil and waste plastics to fuel. J Mater Cycles Waste Manag 6(1):20-26

41. Zhong L, Zhang YF (2008) Sub molten salt method recycling red mud. Chin J Nonferr Met 18:70-73

42. Zheng XF (2010) Recycling technology of aluminum and sodium from low temperature Bayer progress red mud. Shandong Metall 32:16-17

43. Fotini K (2008) An innovative geotechnical application of bauxite residue. Electron J Geotech Eng 13/G:1-9

44. Dimas DD, Ioanna P, Panias D (2009) Utilization of alumina red mud for synthesis of inorganic polymeric materials. Miner Process Extr Metall Rev 30(3):211-239

45. Zhang G, He J, Gambrell RP (2010) Synthesis, characterization, and mechanical properties of red mud-based geopolymers. Transp Res Rec 2167:1-9

46. Liu Wanchao, Yang Jiakuan, Xiao Bo (2009) Review on treatment and utilization of bauxite residues in China. Int $\mathrm{J}$ Min Proces 93:220-231

47. Qiu XR, Qi YY (2011) Reasonable utilization of red mud in the cement industry. Cem Technol 6:103-105

48. Cooper MB (2005) Naturally Occurring Radioactive Material (NORM) in Australian Industries. EnviroRad report ERS-006 
prepared for the Australian Radiation Health and Safety Advisory Council

49. Pinnock W, Graham W (1987) Radioactivity in Jamaican Bauxite Waste. In: Proc. Int. Conf., Bauxite Tailings, Kingston, Jamaica, pp. 113-117

50. Nuccetelli C, Pontikes Y, Leonardi F, Trevisi R (2015) New perspectives and issues arising from the introduction of (NORM) residues in building materials: a critical assessment on the radiological behaviour. Constr Build Mater 82:323-331

51. Podgorodetskiy G, Gorbunov V, Panov A, Gorbachev S (2015) Complex Additives on the basis of bauxite residue for intensification of iron-ore sintering and pelletising. Bauxite Residue Valorization Conference, Leuven, pp. 147-156

52. EU MSCA-ETN-European Training Network for zero-waste valorization of Bauxite Residue (Red Mud) project on; website, http://etn.redmud.org

53. Jamaican Information Service (10th October 2014) Jamaica has full ownership of Rare Earths pilot plant. Government of Jamaica
54. Borra CR, Mermans, Blanpain B, Pontikes Y, Binnemans K, Van Gerven $T$ (2015) Selective leaching of rare earths from bauxite residue after sulphation roasting. Bauxite Residue Valorization Conference, Leuven, pp. 301-307

55. Tsakanika L-A, Ochsenkuhn-Petropoulou M (2015) Separation and recovery of rare earths after red mud leaching by cationexchange chromatography. Bauxite Residue Valorization Conference, Leuven, pp. 309-315

56. Deady EA, Mouchos E, Goodenough K, Williams BJ, Wall F (2016) A review of the potential for rare-earth element resources from European red muds: examples from Seydisehir, Turkey and Parnassus-Giona, Greece. Min Mag 80(1):43-61

57. Petropulu MO, Lyberopulu T, Parissakis G (1995) Selective separation and determination of scandium, yttrium and lanthanides in red mud by a combined ion exchange/solvent extraction method. Anal Chim Acta 315:231-237

58. Orbite Technologies Inc., PCT patent WO 2013/104059

59. Purgo Limited, British Patent Application GB1522152.6 (2015) 